\title{
Evaluation of the Antibacterial and Antioxidant Activity of Mimosa rubicaulis and Reinwardtia indica
}

\author{
Roshani Gurung (D), Sundar Adhikari iD, and Kalpana Parajuli (iD \\ Department of Pharmaceutical Sciences, School of Health and Allied Sciences, Pokhara University, Pokhara-30, \\ Kaski 33700, Nepal
}

Correspondence should be addressed to Kalpana Parajuli; kalpanapril@gmail.com

Received 24 September 2019; Revised 18 March 2020; Accepted 10 October 2020; Published 10 November 2020

Academic Editor: Man Hee Rhee

Copyright (c) 2020 Roshani Gurung et al. This is an open access article distributed under the Creative Commons Attribution License, which permits unrestricted use, distribution, and reproduction in any medium, provided the original work is properly cited.

\begin{abstract}
Many plants have the property of wound healing, but most of the people are using costly allopathic medicine for the wound. This might be due to lack of awareness about the traditional uses and lack of scientific study of ethnomedicinal plants. So, this study aimed to carry out the antibacterial and antioxidant activity of two medicinal plants which are used traditionally for wound healing activity, i.e.,Mimosa rubicaulis and Reinwardtia indica. Different parts of Mimosa rubicaulis (root, stem, and leaves) and Reinwardtia indica (flower and leaves) were used for the study. Extractions were done by maceration using ethanol as solvent. Antibacterial activity was carried out by the well diffusion method, and antioxidant activities were screened by DPPH radical scavenging and NO scavenging assays. Extract of M. rubicaulis has shown a weak zone of inhibition towards $S$. aureus and $P$. vulgaris whereas $R$. indica has shown no zone of inhibition towards selected bacterial strains. Leaf, root, and stem extracts of M. rubicaulis have shown potent antioxidant activity, i.e., $\mathrm{IC}_{50}$ value of $9.8 \mu \mathrm{g} / \mathrm{ml}, 10.19 \mu \mathrm{g} / \mathrm{ml}$, and, $13.64 \mu \mathrm{g} / \mathrm{ml}$, respectively. Similarly, leaf extract of $R$. indica exhibited antioxidant activity with an $\mathrm{IC}_{50}$ value of $19.73 \mu \mathrm{g} / \mathrm{ml}$. The percentage inhibition of NO radicals of root and stem of $M$. rubicaulis and leaves of $R$. indica was $31 \%, 21 \%$, and $22 \%$, respectively. Out of these two plant species, $M$. rubicaulis had shown antibacterial activity towards selected microorganism, but antioxidant activity was shown by both plant species. These properties on above mentioned two plant species might help for the development of a marketed formulation for antibacterial and wound-healing agent since wound healing is promoted by antibacterial and antioxidant activities.
\end{abstract}

\section{Introduction}

In developing countries, infectious diseases due to bacteria are the main causes of morbidity and mortality among the general population [1]. In the present context, various antibiotics have been discovered for the treatment of infectious diseases. It was assumed that infectious diseases will no longer exist after the discovery of antibiotics [2]. However, the increased use of antibiotics has led to the drug-resistant strain of bacteria which in turn has resulted in the emergence of new infectious diseases. So, it is a necessity and challenge to develop new antibiotics with novel mechanisms of action to overcome the problem of antibiotic resistance [3].

Today's another issue is that many people in this fastgrowing world are suffering from diseases such as heart disease, cancer, Alzheimer's disease, neurological disorders, hypertension, diabetes mellitus, renal failure, liver diseases, and early aging [4] due to exposure on various exogenous sources such as radiations, various toxic chemicals, and pollution [5]. That might be due to the generation of free radicals [6] which are capable of attacking the healthy cells of the body, causing them to lose their structure and function [7].

An antioxidant is a molecule that inhibits the oxidation of other molecules and terminates the chain reactions of free radicals by donating an electron or hydrogen atom to free radical causing the stable chemicals [8]. Free radicals can be scavenged by the in vivo production of antioxidant compounds, but the endogenous antioxidants are insufficient to remove them completely and maintain a balance. As a result, 
dietary antioxidants are required to counteract excess free radicals [9].

Different phytochemicals are present in plants such as terpenoids, aromatic and aliphatic compounds, carbohydrates, lactams, peptides, and quinines where these chemicals are responsible for antimicrobial activity of some plants [2]. Some plants have natural antioxidant activity as they may contain vitamin $\mathrm{C}$, vitamin $\mathrm{E}$, carotenes, flavonoids, isoflavones, anthocyanin, catechin, and isocatechin [10]. Due to the presence of such phytochemicals, plants are widely used as medicine ethnomedicinally. The primary benefits of using plant-derived medicines are relatively safer with fewer side effects than synthetic alternatives, offering profound therapeutic benefits and more affordable treatments [11].

Although plants have traditional uses as medicine, which are safer for use, most of the people use allopathic medicine for their primary healthcare. Also, traditionally used plants have not been extensively studied scientifically yet. So, the main aim of this study was to determine the antibacterial and antioxidant activity of Mimosa rubicaulis and Reinwardtia indica which are used for wound-healing activity traditionally.

Mimosa rubicaulis belongs to the Leguminosae family. It is a straggling shrub. Traditionally, it is used in peptic ulcer, dislocated bone, sprains, backache, hemorrhoids, wound, and fever [12]. Reinwardtia indica belongs to the Linaceae family. It is an erect perennial herb about $1 \mathrm{~m}$ high. Traditionally, plant is applied to boils, headaches, scabies, wounds, bee stings, insect's bites, and thorn stabs [12].

\section{Materials and Methods}

2.1. Plant Material. Different parts of plant samples, i.e., root, stem, and leaves of $M$. rubicaulis, and flower and leaves of $R$. indica were collected from Pokhara Valley, Nepal. Proper identification of plants was done under the supervision of local traditional healers. The collected samples of crude drugs were properly identified by the botanist Prof. Dr. Radhe Shyam Kayastha and preserved in the Pharmacognosy Laboratory of School of Health and Allied Sciences, Pokhara University, Nepal.

2.2. Chemicals. Ascorbic acid (Loba Chemie), dimethyl sulphoxide (Alpha Chemika), 2,2-diphenyl-1-picrylhydrazyl (DPPH) (Wako Pure Chemical), methanol (Fischer Scientific), Muller Hilton Agar (Himedia Laboratories), N-(1naphthyl)ethylenediamine (NEDD) (Loba Chemie), sodium nitroprusside (Fischer Scientific), and all the other required chemicals were obtained from various chemical suppliers as well from the Laboratory of School of Health and Allied Sciences, Pokhara University, Pokhara-30, Kaski, Nepal.

2.3. Extraction. Shade-dried samples were extracted by a double maceration process using ethanol as solvent. For this, $25 \mathrm{~g}$ of each sample was weighed and macerated in $175 \mathrm{ml}$ ethanol (ethanol: crude drug=7:1) for $24 \mathrm{hr}$. After $24 \mathrm{hr}$, filtration was done by using filter paper and the obtained residue was again macerated with $175 \mathrm{ml}$, i.e., the same volume of ethanol for $24 \mathrm{hr}$. Then, obtained filtrates were mixed and solvent evaporation was done by using a rotatory vacuum evaporator and collected in the Petri dish. Again, the samples were kept in a vacuum desiccator for the complete removal of the solvent present in the extract. The obtained dried extracts were collected in a sample vial. They were labeled with symbols using alphabetical letters and preserved in the refrigerator.

\section{Antibacterial Activity}

3.1. Bacterial Strain and Its Growth Condition. The bacterial strains, i.e., one Gram-positive bacterium, Staphylococcus aureus, and two Gram-negative bacteria, Escherichia coli and Proteus vulgaris, were obtained from the National Public Health Laboratory (NPHL), Kathmandu, and growth conditions were maintained according to the method described previously [3] with some modifications.

3.2. Well Diffusion Method. The well diffusion method was done to determine the antibacterial activity of plant extract according to the method described previously [13] with some modifications. Wells $(8 \mathrm{~mm}$ diameter and about $2 \mathrm{~cm}$ apart) were made in each of the plates using a sterile cork borer. A stock solution of each plant extract was prepared at a concentration of $1 \mathrm{mg} / \mathrm{ml}$ and $2 \mathrm{mg} / \mathrm{ml}$ in $10 \%$ dimethyl sulfoxide (DMSO) solution. A volume of $100 \mu \mathrm{l}$ of stock solution of plant extract was added by sterile syringe into the wells and allowed to diffuse at room temperature for $2 \mathrm{hr}$. Ofloxacin and cefpodoxime were taken as positive control where $10 \%$ DMSO solution was taken as a negative control. Then, medium plates were incubated at $37^{\circ} \mathrm{C}$ for $24 \mathrm{hr}$ in an incubator. After $24 \mathrm{hr}$, zones of inhibition were measured.

3.3. Antioxidant Activity Assay. The antioxidant activity of the plant extract was determined using DPPH radical scavenging assay and nitric oxide (NO) radical scavenging assay methods.

3.4. DPPH Radical Scavenging Assay. DPPH is a free radical-generating compound which is used to determine the radical scavenging activity of extracts. It is a rapid, simple, and inexpensive method to measure antioxidant capacity. The odd electron in the DPPH free radical gives a strong absorption maximum at $517 \mathrm{~nm}$ and has a deep purple color [5].

DPPH free radical assay was performed according to the method described previously [14] with some modifications. In brief, $2 \mathrm{ml}$ of different extract solution was mixed with $2 \mathrm{ml}$ of DPPH solution $(60 \mu \mathrm{M})$ and allowed to stand for 30 min. Then, absorbance of each plant samples was measured at $517 \mathrm{~nm}$ by using a UV spectrophotometer. Radical scavenging activity of each sample was calculated by using the following formula: 
radical scavenging activity $(\%)=\left[\frac{\left(A_{0}-A_{s}\right)}{A_{0}}\right] \times 100 \%$,

where $A_{0}=$ absorbance of control and $A_{S}=$ absorbance of a sample. Control is the test solution without a sample. A similar process was done with an ascorbic acid solution of concentrations $(100 \mu \mathrm{g} / \mathrm{ml}, 10 \mu \mathrm{g} / \mathrm{ml}$, and $1 \mu \mathrm{g} / \mathrm{ml})$. Ascorbic acid was taken as a positive control.

\subsection{NO Radical Scavenging Assay}

3.5.1. Preparation of Griess Reagent. A total amount of $0.25 \mathrm{~g}$ of NEDD was mixed in sufficient deionized water to produce $250 \mathrm{ml}$ of $0.10 \%$ of the NEDD solution. Then, $1 \%$ sulfanilamide solution was prepared by dissolving $2.50 \mathrm{~g}$ of sulfanilamide in $5 \%$ phosphoric acid to produce $250 \mathrm{ml}$. Finally, $500 \mathrm{ml}$ of Griess reagent was prepared by mixing NEDD solution and sulfanilamide solution which was then stored in a refrigerator and used before $8 \mathrm{hr}$.

3.5.2. Determination of NO Radical Scavenging Assay. In NO scavenging assay, incubation of solutions of sodium nitroprusside in phosphate buffer saline at $250^{\circ} \mathrm{C}$ for $2.5 \mathrm{hr}$ resulted in a linear time-dependent nitrite production [15]. The quantities of NO produced is determined using Griess reagent by the development of purple to pink color during the diazotization of nitrite with sulfanilamide and its subsequent coupling with NEDD. The absorbance is observed at $548 \mathrm{~nm}$ on UV spectrophotometer [16].

NO radical scavenging activity was measured by the method described previously [1] with slight modifications. In brief, $1 \mathrm{ml}$ of test samples of different concentrations were taken in a test tube and mixed with $1 \mathrm{ml}$ of sodium nitroprusside $(5 \mathrm{mM})$ solution and test tubes were incubated for $2.5 \mathrm{hr}$ at $29^{\circ} \mathrm{C}$. After $2.5 \mathrm{hr}, 2 \mathrm{ml}$ Griess reagent was added to each test tubes and absorbance was measured at $548 \mathrm{~nm}$ in a UV spectrophotometer after $30 \mathrm{~min}$ incubation at room temperature. The radical scavenging effects of test samples were calculated by the following formula:

radical scavening activity $(\%)=\left[\frac{A_{0}-A_{s}}{A_{0}}\right] \times 100 \%$,

where $A_{o}=$ absorbance of control and $A_{s}=$ absorbance of sample.

Control is the test solution without the test sample. A similar process was done for curcumin solution used as positive control, i.e., standard solution.

\section{Results}

4.1. Extraction Yield Value. The extract yield \% was calculated using equation (3). The extract yield \% of the plant sample is shown in Table 1 . The extract yield percentage was relatively higher in root and leaves of $M$. rubicaulis, and flower of $R$. indica while relatively lower in the stem of $M$. rubicaulis and leaves of $R$. indica.
TABLE 1: Extraction yield value and symbol code used for plant samples.

\begin{tabular}{lccc}
\hline Scientific name & $\begin{array}{c}\text { Parts } \\
\text { used }\end{array}$ & Sample code & $\begin{array}{c}\text { Percentage yield value } \\
\text { (ethanol) }\end{array}$ \\
\hline \multirow{3}{*}{ Mimosa rubicaulis } & Root & A & 8 \\
& Stem & B & 3.2 \\
& Leaves & C & 11.52 \\
\hline \multirow{2}{*}{ Reinwardtia indica } & Flower & D & 7.95 \\
& Leaves & E & 3.52 \\
\hline
\end{tabular}

$$
\% \text { yield }=\frac{\text { weight of extract yield }}{\text { weight of crude sample taken }} \times 100 \% \text {. }
$$

4.2. Antibacterial Activity. Each of different parts of plant extract, i.e., root, stem, and leaves of $M$. rubicaulis, and flower and leaves of $R$. indica were used to measure and compare the zone of inhibitions with the standard antibiotics ofloxacin and cefpodoxime at a concentration of $1 \mathrm{mg} / \mathrm{ml}$ and $2 \mathrm{mg} / \mathrm{ml}$ in $10 \%$ DMSO in test microorganisms, i.e., two Gram-negative bacteria, which are E. coli and P. vulgaris, and one Gram-positive bacteria, which are $S$. aureus. The standard drug, ofloxacin had shown zone of inhibition towards E. coli $(45 \mathrm{~mm})$, P. vulgaris $(48 \mathrm{~mm})$, and $\mathrm{S}$. aureus $(34 \mathrm{~mm})$, respectively. Similarly, cefpodoxime had shown zone of inhibition towards E. coli $(36 \mathrm{~mm}), P$. vulgaris $(34 \mathrm{~mm})$, and S. aureus $(24 \mathrm{~mm})$, respectively. The root extract of M. rubicaulis was found to have a weak zone of inhibition towards S. aureus, i.e., $12 \mathrm{~mm}$, and leaves and stem extracts were found to have a weak zone of inhibition towards $P$. vulgaris, i.e., $11 \mathrm{~mm}$ and $11 \mathrm{~mm}$, respectively. However, the flower and leaves extract of $R$. indica were found to have no zone of inhibition towards the selected bacteria even in $2 \mathrm{mg} / \mathrm{ml}$ of concentration. At a concentration of $1 \mathrm{mg} / \mathrm{ml}$, none of the extracts had shown a zone of inhibition towards the selected organism.

\subsection{Antioxidant Activity}

4.3.1. DPPH Radical Scavenging Activity. The result of the DPPH radical scavenging assay is shown in Table 2 and Figure 1. Among the studied plant extracts, root, leaves, and stem extracts of $M$. rubicaulis exhibited high antioxidant activity in DPPH free radical scavenging assay as $89 \%, 88 \%$, and, $81 \%$, respectively, in $100 \mu \mathrm{g} / \mathrm{ml}$. The half maximal inhibitory concentration $\left(\mathrm{IC}_{50}\right)$ value of leaves extract was $9.80 \mu \mathrm{g} / \mathrm{ml}$. Similarly, the $\mathrm{IC}_{50}$ value of root extract and stem extract was found to be $10.19 \mu \mathrm{g} / \mathrm{ml}$ and $13.64 \mu \mathrm{g} / \mathrm{ml}$, respectively, which was very close to that of standard (ascorbic acid) as $9.99 \mu \mathrm{g} / \mathrm{ml}$. The leaves extract of $R$. indica exhibited $\mathrm{DPPH}$ radical scavenging assay as $34 \%$ with an $\mathrm{IC}_{50}$ value of $19.73 \mu \mathrm{g} / \mathrm{ml}$, but flower extract of $R$. indica exhibited low antioxidant activity, i.e., $4 \%$ with an $\mathrm{IC}_{50}$ value of $165.36 \mu \mathrm{g} /$ ml. $\mathrm{IC}_{50}$ is defined as the amount of antioxidant required to inhibit $50 \%$ of DPPH free radicals under the experimental conditions. 
TABLE 2: Result of $\mathrm{IC}_{50}$ value of samples and standard drugs from DPPH scavenging activity and NO scavenging activity.

\begin{tabular}{lcc}
\hline Samples & $\begin{array}{c}\text { DPPH scavenging } \\
\text { activity } \mathrm{IC}_{50}(\mu \mathrm{g} / \mathrm{ml})\end{array}$ & $\begin{array}{c}\text { NO scavenging activity } \\
\mathrm{IC}_{50}(\mu \mathrm{g} / \mathrm{ml})\end{array}$ \\
\hline A & 10.19 & 0.23 \\
$\mathrm{~B}$ & 13.64 & 0.32 \\
$\mathrm{C}$ & 9.80 & 0.58 \\
$\mathrm{D}$ & 165.36 & 1.82 \\
E & 19.73 & 0.28 \\
AA & 9.99 & - \\
Curcumin & - & 0.12 \\
\hline
\end{tabular}

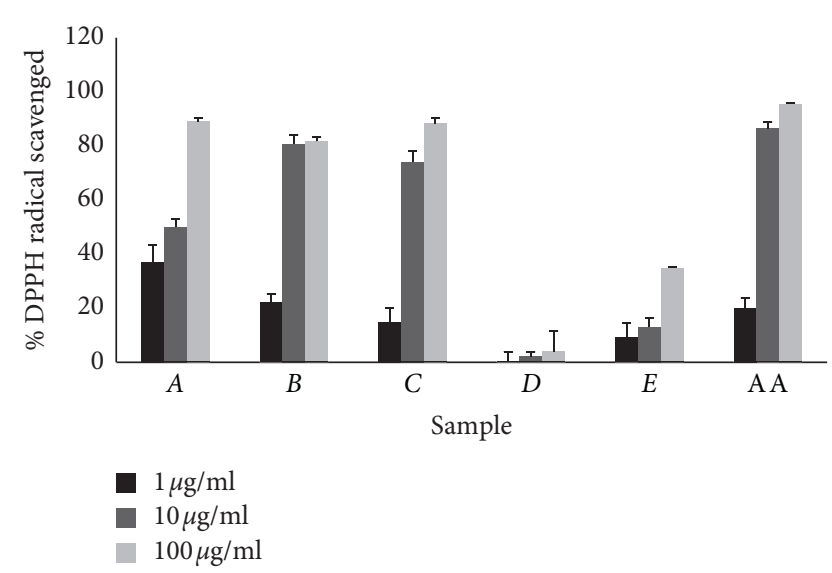

FIGURE 1: Graphical representation of percentage scavenging of DPPH free radicals by extract and ascorbic acid (AA) at $517 \mathrm{~nm}$. The error bar represents the standard deviation of three independent determinations performed in triplicate of sample size $(n=6)$.

4.4. NO Scavenging Activity. The NO scavenging activity of different plant extracts was determined by using Griess reagent. Sodium nitroprusside was used as nitric oxideproducing agent. The root and stem of $M$. rubicaulis and leaves of $R$. indica had shown NO scavenging activity at higher concentrations $(100 \mu \mathrm{g} / \mathrm{ml})$, i.e., $31 \%$ and $21 \%$ and $22 \%$, respectively. The root, stem, and leaves extracts of $M$. rubicaulis had shown $\mathrm{IC}_{50}$ value as slightly higher than that of standard drug curcumin as $0.23 \mu \mathrm{g} / \mathrm{ml}$, $0.32 \mu \mathrm{g} / \mathrm{ml}$, and $0.58 \mu \mathrm{g} / \mathrm{ml}$, respectively. Similarly, the extract of $R$. indica had also exhibited higher $I_{50}$ value to that of standard, which is shown in Figure 2 and Table 2.

The result of the $\mathrm{IC}_{50}$ value of samples from $\mathrm{DPPH}$ scavenging assay against the DPPH free radical and NO scavenging assay against the nitric oxide free radical is in Table 2. Ascorbic acid had shown a good $\mathrm{IC}_{50}$ value of $9.99 \mu \mathrm{g} / \mathrm{ml}$ against DPPH free radical, but curcumin had exhibited an $\mathrm{IC}_{50}$ value of $0.12 \mu \mathrm{g} / \mathrm{ml}$ towards nitric oxide free radical. However, both the extracts of plant samples had shown $\mathrm{IC}_{50}$ value nearly similar to that of standard as ascorbic acid and curcumin which is shown in Table 2.

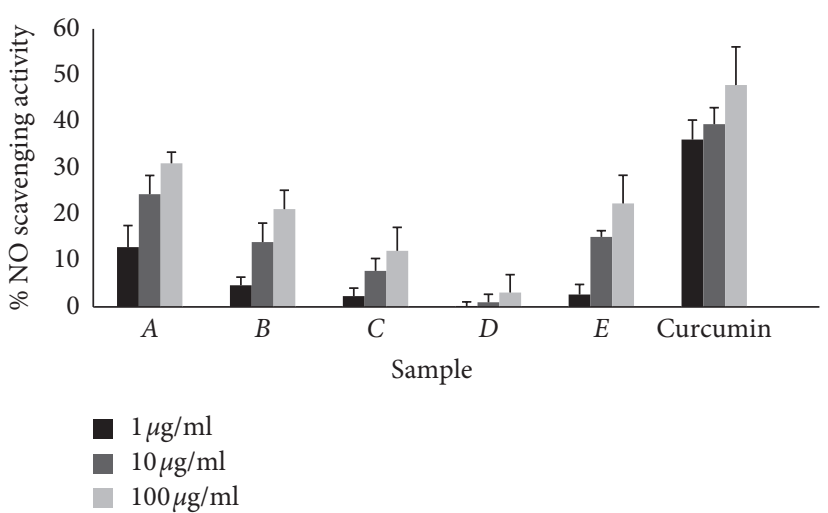

FIGURE 2: Graphical representation of percentage scavenging of NO free radicals by extract and curcumin at $548 \mathrm{~nm}$. The error bar represents the standard deviation of three independent determinations performed in triplicate of sample size $(n=6)$.

\section{Discussion}

Antibacterial activities were assayed to determine the zone of inhibition towards E. coli, P. vulgaris, and S. aureus at a concentration of $1 \mathrm{mg} / \mathrm{ml}$ and $2 \mathrm{mg} / \mathrm{ml}$. The root, stem, and leaves extract of M. rubicaulis were found to have a negligible zone of inhibition, but flower and leaves of $R$. indica were found to have no zone of inhibition as compared to the reference drug ofloxacin and cefpodoxime even at a concentration of $2 \mathrm{mg} / \mathrm{ml}$, but no zone of inhibition was shown by any selected plants extract at $1 \mathrm{mg} / \mathrm{ml}$ which is shown in Table 2. This activity was comparatively lower than that observed in methanolic leaves extract of $M$. rubicaulis by the agar diffusion method against Gram-negative (E. coli), at a concentration of $15 \mathrm{mg} / \mathrm{ml}$ [17] and methanolic root extract of M. rubicaulis at a concentration of $1000 \mathrm{mcg} / \mathrm{ml}$ (E. coli) by the cup plate method [18]. No zones of inhibition were seen for both ethanolic leaves and root extracts of M. rubicaulis at $2 \mathrm{mg} / \mathrm{ml}$ by using a well diffusion method towards E. coli. It may be due to the solvent effect as well as concentration effect.

The antioxidant activities were assayed by DPPH free radical scavenging and NO scavenging assays. The DPPH free radical is a simple and acceptable method to evaluate the antioxidant activity of plant extracts. The DPPH forms a stable molecule on accepting an electron or a hydrogen atom and thus has applications in the determination of radical scavenging activity of natural products as well as synthetic compounds [19]. The leaves, root, and stem extracts of $M$. rubicaulis exhibited high antioxidant activity by DPPH free radical scavenging assay with an $\mathrm{IC}_{50}$ value of $9.80 \mu \mathrm{g} /$ $\mathrm{ml}, 10.19 \mu \mathrm{g} / \mathrm{ml}$, and $13.64 \mu \mathrm{g} / \mathrm{ml}$, respectively, which was very close to that of standard (ascorbic acid) shown in Table 2 and Figure 1. It may suggest that the extract might contain an electron donor molecule that reacts with free radicals to convert them to more stable products and terminate radical chain [20].

NO is an important chemical mediator involved in the regulation of various physiological processes. NO or RNS (reactive nitrogen species) formed during their reaction with 
oxygen or with superoxides, such as $\mathrm{NO}_{2}, \mathrm{~N}_{2} \mathrm{O}_{4}$, and $\mathrm{N}_{3} \mathrm{O}_{4}$ which are very reactive and are responsible for altering the structural and functional behavior of many cellular components [21]. Scavengers of nitric oxide compete with oxygen leading to reduced production of nitrite ions [22]. Among the plant extract under study, the root extract of M. rubicaulis showed the NO scavenging activity by $31 \%$ at $100 \mu \mathrm{g} / \mathrm{ml}$ and other extracts showed less activity. The $\mathrm{IC}_{50}$ value of both the plant samples had shown similar value to that of the standard drug, curcumin, which is shown in Table 2 . The ability of the extract to generate the nitrite in decreased amount may be due to the capacity to decompose the sodium nitroprusside in vitro due to the presence of different phytoconstituents mainly phenolic compounds such as flavonoids responsible to scavenge the free radical by competing with the oxygen molecule of NO free radical, thus leading to antioxidant activity [16]. This activity was comparatively lower than that observed in water and carbinol extract of leaves of $R$. indica in previous studies [1] whereas ethanolic leaves extract of $R$. indica showed less activity in this study. This may be due to the solvent effect.

\section{Conclusion}

Out of two plant species, $M$. rubicaulis had shown antibacterial activity towards $P$. vulgaris and $S$. aureus, but antioxidant activity was shown by both plant species. Antibacterial and antioxidant activities found in plant species might help in formulation development which could be marketed as antibacterial and wound-healing agents in future days.

\section{Data Availability}

The data will be available upon request to the corresponding author.

\section{Conflicts of Interest}

The authors involved in this research declare that there are no conflicts of interest regarding the publication of this paper.

\section{Acknowledgments}

The authors would like to express their sincere thanks to Lecturer Suresh Jaiswal, Pokhara University, for helping them during the test of antibacterial activity. The authors would like to express their sincere thanks to Prof. Dr. Radheshyam Kayastha, Prithivi Narayan Campus, Tribhuvan University, for helping in the identification of plant samples. This is a part of the thesis work of Master of Pharmaceutical Sciences, and all the materials needed for research were fully supported by the Department of Pharmaceutical Sciences, Pokhara University.

\section{References}

[1] S. Abha, V. Swati, and R. K. Shukla, "Preliminary phytochemical screening, antibacterial and nitric oxide radical scavenging activities of Reinwardtia indica leaves extract,"
International Journal of Pharm Tech Research, vol. 5, no. 4, pp. 1670-1678, 2013.

[2] M. Ahmad and M. Wajid, "Plants as potential source of antimicrobial agents," Journal of Pharmacy and Alternative Medicine, vol. 2, no. 3, pp. 18-25, 2013.

[3] C. Valgas, S. M. d. Souza, E. F. A. Smânia Jr., and A. Smania Jr., "Screening methods to determine antibacterial activity of natural products," Brazilian Journal of Microbiology, vol. 38, no. 2, pp. 369-380, 2007.

[4] H.-Y. Cheng, T.-C. Lin, K.-H. Yu, C.-M. Yang, and C.-C. Lin, "Antioxidant and free radical scavenging activities of Terminalia chebula," Biological \& Pharmaceutical Bulletin, vol. 26, no. 9, pp. 1331-1335, 2003.

[5] M. Antolovich, P. D. Prenzler, E. Patsalides, S. McDonald, and K. Robards, "Methods for testing antioxidant activity," The Analyst, vol. 127, no. 1, pp. 183-198, 2001.

[6] K. Pandey, P. K. Sharma, and R. Dudhe, "Antioxidant and anti-inflammatory activity of ethanolic extract of Parthenium hysterophorus Linn," Asian Journal of Pharmaceutical and Clinical Research, vol. 5, no. 4, pp. 28-31, 2012.

[7] D. Singh, M. Mishra, M. Gupta et al., "Nitric oxide radical scavenging assay of bioactive compounds present in methanol extract of Centella asiatica," International Journal of Pharmacy and Pharmaceutical Science Research, vol. 2, no. 3, pp. 42-44, 2012.

[8] A. Prakash, F. Rigelholf, and M. Eugene, "Antioxidant activity,” Analytical Progress, vol. 19, no. 2, pp. 1-6, 2001.

[9] C. Kaur and H. C. Kapoor, "Anti-oxidant activity and total phenolic content of some Asian vegetables," International Journal of Food Science and Technology, vol. 37, no. 2, pp. 153-161, 2002.

[10] S. Ahmad, M. A. Arshad, S. Ijaz et al., "Review on methods used to determine antioxidant activity," International Journal of Multidisciplinary Research and Development, vol. 1, no. 1, pp. 35-40, 2014.

[11] T. Selvamohan, V. Ramadas, and S. S. S. Kishore, "Antimicrobial activity of selected medicinal plants against some selected human pathogenic bacteria," Advances in Applied Science Research, vol. 3, no. 5, pp. 3374-3381, 2012.

[12] N. P. Manandhar, Plants and People of Nepal, Timber Press, Portland, OR, USA, 2002.

[13] A. Sen and A. Batra, "Evaluation of antimicrobial activity of different solvent extracts of medicinal plant: Melia azedarach L," International Journal of Current Pharmaceutical Research, vol. 4, no. 2, pp. 67-73, 2012.

[14] M.-K. Kim, H.-S. Lee, E.-J. Kim et al., "Protective effect of aqueous extract of Perilla frutescens on tert-butyl hydroperoxide-induced oxidative hepatotoxicity in rats," Food and Chemical Toxicology, vol. 45, no. 9, pp. 1738-1744, 2007.

[15] L. C. Green, D. A. Wagner, J. Glogowski, P. L. Skipper, J. S. Wishnok, and S. R. Tannenbaum, "Analysis of nitrate, nitrite, and $[15 \mathrm{~N}]$ nitrate in biological fluids," Analytical Biochemistry, vol. 126, no. 1, pp. 131-138, 1982.

[16] V. P. Karthik and D. C. David, "In vitro nitric oxide scavenging activity of ethanol extract of Canthium coramandelium," International Journal of Pharma and Bio Sciences, vol. 6, no. 4, pp. P695-P700, 2015.

[17] A. Shakoor, A. U. Rahman, G. Zaib et al., "Biological screening of Albizia lebbek L. and Mimosa himalayana gamble (mimosaceae)," Journal of Medicinal Plant Research, vol. 8, no. 20, pp. 731-735, 2014.

[18] A. R. Ganji and A. C. Yedla, "Antibacterial investigation on different root extracts of Mimosa rubicaulis Lam," 
International Journal of Pharmacognosy and Phytochemical Research, vol. 2, no. 4, pp. 18-21, 2010.

[19] M. A. R. Bhuiyan, M. Z. Hoque, and S. J. Hossain, "Free radical scavenging activities of methanol extracts of three Bangladeshi medicinal plants," The Pharma Innovation Journal, vol. 1, no. 12, pp. 83-88, 2009.

[20] L. A. Figueroa, L. B. Navarro, M. P. Vera, and V. L. Petricevich, "Antioxidant activity, total phenolic and flavonoid contents, and cytotoxicity evaluation of Bougainvillea xbuttiana," International Journal of Pharmacy and Pharmaceutical Sciences, vol. 6, no. 5, pp. 497-502, 2014.

[21] R. Parul, S. K. Kundu, and P. Saha, "In vitro nitric oxide scavenging activity of Portuguese shrubs: Pterospartum tridentatum, Cytisus scoparius and Erica spp." Journal of Medicinal Plants Research, vol. 3, no. 11, pp. 886-893, 2013.

[22] A. Mehandzhiyski, D. Batovska, D. Dimitrov, L. Evstatieva, and K. Danova, "Nitric oxide scavenging activity of in vitro cultured Balkan medicinal and aromatic plants," Bulgarian Journal of Agricultural Science, vol. 19, no. 2, pp. 31-34, 2013. 